\title{
Galardón a Irene Papás
}

La Fundación para el Parlamentarismo y la Democracia otorgó el Primer Premio para las Griegas y los Griegos de Reconocimiento mundial a Irini Papá. El galardón se entregó a la actriz de fama mundial por el Presidente del Parlamento (Voulí) D. Sioufas, en presencia del Primer Ministro K. Karamanlís, de los ex Primeros Ministros K. Simitis y K. Mitsotakis, de los ex presidentes del Parlamento Ap. Kaklamanis y A. BenakiPsaruda, y de muchos diputados. La premiación coincidió con la celebración del Día Internacional del Teatro, el 27 de marzo de 2009.

Emocionada, la señora Papá destacó que esta premiación "posee especial valor y simbolismo, pues me premia el Parlamento y mi patria». Respondiendo al deseo del señor Sioufas «de que continúe usted por muchos años todavía su labor para el arte, para Grecia y el mundo", la señora Papá habló de su "Escuela», el viejo taller de Sánitas, en la calle del Pireo, donde quiere llevar las tragedias y la obra que ha presentado todos estos años en el exterior.

«Este galardón expresa el deseo individual y colectivo de todo griego y toda griega de que se premie a Irini Papá», dijo en su discurso el señor Sioufas, quien destacó que la señora Papá se consagró en el firmamento artístico internacional "no sólo como la gran actriz, sino como la gran actriz griega". Describió a la señora Papá, además, con las palabras del gran director de teatro Manuel de Oliveira como «la bellísima y majestuosa figura que encarna el alma femenina en su más profunda expresión". Es la imagen de la Grecia de todas las épocas, «madre de un río", fuente de toda la cultura occidental. 